\title{
Multiple Intestinal Lymphoma
}

\author{
B. MASTALIER B ${ }^{1}$, VIOLETA DEACONESCU ${ }^{1}$, W. ELAIAHC DRĂGHICI ${ }^{2}$, CRISTIANA POPP ${ }^{3}$, \\ SABINA ZURAC ${ }^{3}$, M.BALEA $^{4}$, MIHAELA TEVET ${ }^{4}$, C. BOTEZATU ${ }^{1}$ \\ ${ }^{1}$ Surgical Clinic, "Colentina” Hospital, Bucharest, Romania \\ ${ }^{2}$ ICU, "Colentina" Hospital, Bucharest, Romania \\ ${ }^{3}$ Pathology Unit, "Colentina" Hospital, Bucharest, Romania \\ ${ }^{4}$ Haematology Unit, "Colentina" Hospital, Bucharest, Romania
}

\begin{abstract}
Gastrointestinal tract is the most common location for extralymphonodular lymphomas. The small intestine is affected only in $9 \%$ of the cases. Intestinal lymphoma may have single or multiple location. This paper describes a case of multiple location in the small intestine of a non-Hodgkin B-cell in a 53 years old patient, who was initially diagnosed with bilateral pneumonia with pleurisy with $E$. coli, steeper on the right side, but the persistence of symptoms as fever, malaise, despite appropriate treatment, required further investigation. The CT exam observed fluid collection in the hypogastrium around a digestive loop. The patient underwent surgery, the intraoperative foundings being: a large mesenteric tumor $\sim 5 \mathrm{~cm}$ in diameter, a terminal ileal mesenteric tumor, a mesenteric tumor $\sim 6 \mathrm{~cm}$ in diameter, omentum with nodular formations, a tumor $\sim 3.3 / 2.5 .1 \mathrm{~cm}$ in the abdominal wall, pseudotumoral appendix. Segmental enterectomy with entero-enterostomy, excision of mesenteric tumors, appendectomy and omentectomy were performed. Pathological diagnosis was non-Hodgkin marginal zone B-cell MALT type lymphoma of the small intestine with extension to the appendix, meso, omentum and abdominal wall. Postoperatively, the patient received chemotherapy for remission.
\end{abstract}

Key words: lymphoma, small intestine, mesenteric tumors, enterectomy.

Lymphoma is a cancer with the lymphocytes or lymphoblasts as a starting point. The disease can only affect the lymphatic system or can locate extralymphonodular primary level. It represents approximately $4 \%$ of cancers and it is more common in developed countries. The etiology is unknown but possible risk factors are: $\mathrm{HCV}$ )

- viral infection (ex: Epstein-Barr virus, HIV,

- bacterial infections (ex: H. pylori)

- chronic state of immunosuppression (ex: posttransplant)

- chemotherapy in history (especially with alkalizing agents) or certain medications (ex: digoxin).

According to current WHO classification of tumors of hematopoietic and lymphoid tissue, lymphomas are divided into:

- Hodgkin's lymphoma (40\%)

- non-Hodgkin's lymphoma (60\%) B cell, $\mathrm{T}$ cell, post-transplant lymphoproliferative disorders. $85 \%$ of them are represented by B cell lymphomas [1].

According to Ann-Arbor modified staging, Hodgkin lymphomas are classified into:

I: tumor confined to the intestine;

II: regional lymphonodular extension;
III: unresectable extra-regional lymph node extension;

IV: extension to other organs intra or extraabdominal.

In children, lymphomas represent $10-15 \%$ of cancers, accounting for the third form of malignnancies. It may sometimes appear as Burkitt lymphoma localized ileocecal [2].

Regarding the location of the small intestine lymphoma, it represents $25 \%$ of primary malignnancies at this level and $40 \%$ of primary gastrointestinal lymphomas location. In most cases, lymphoma occurs in the small intestine as an extranodular location of the systemic disease. As a primary malignancy, individuals with AIDS, celiac disease, organ transplantation, infection with Helicobacter pylori may be involved [3].

In cases with small bowel localisation, the disease sets insidious, symptoms are unspecific, like abdominal cramps, nausea, vomiting, fatigue. Diagnosis is difficult, because imaging examinations such as barium swallow or computer tomography have low sensitivity and specificity [4]. Some cases may present as acute intestinal obstruction, perforation or intestinal invagination, but still complications are rare [5]. 


\section{CASE REPORT}

Patient S.G., 53 years old, from urban environment, known with dermatitis herpetiformis since 1992, ocular trauma by foreign body in 02.2011, diagnosed in 11.2011 (in another hospital) with bilateral pneumonia with pleurisy $E$. coli stronger on the right, accompanied by fever, malaise, inflammatory syndrome, hypochromic microcytic anemia. Given the persistance of symptoms, the patient continued investigation, abdominal ultrasound showing pericecal and periileum pseudotumoral infiltration, hepato-splenomegaly. Abdominal CT 30.11.2012: fluid collection in hypogastrium around a digestive loop, suggesting abscess or blood; liver and spleen may suggest cirrhosis; bilateral pleural effusion (Fig. 1).

On 5/12/2012 the patient was transferred in the "Colentina" Surgical Clinic, presenting right iliac fossa and hypogastrium pain, fever, pale skin and mucous, weakness. Biological: inflammatory syndrome, mild microcytic hypochromic anemia. Echo reaffirms abdomen CT appearance. Persistence pleurisy certified by $\mathrm{Rx}$ heart-lung, right pleural puncture externalises $150 \mathrm{ml}$ serocitrin liquid: sterile culture, normal cytology, erythrocytes, lymphocytes and rare mesothelial cells.

On 13/12/2012 the patient underwent the surgical intervention: adhesion intestinal block with an ileal dilated segment, fixed in the pelvis, corresponding to a large mesenteric $5 \mathrm{~cm}$ in diameter tumor, another mesenteric tumor of the terminal ileum, another mesenteric $6 \mathrm{~cm}$ tumor, omentum with nodular formations, another tumor $(\sim 3.3 / 2.5 .1 \mathrm{~cm})$ in the abdominal wall, pseudotumoral appendix. Extended enterectomy including the 2 tumors with latero-lateral entero-enterostomy, double-layer closure of bowel ends with TA 60 stapler, excision of the mesenteric tumors, appendectomy and omentectomy were performed (Figs. 1-18).
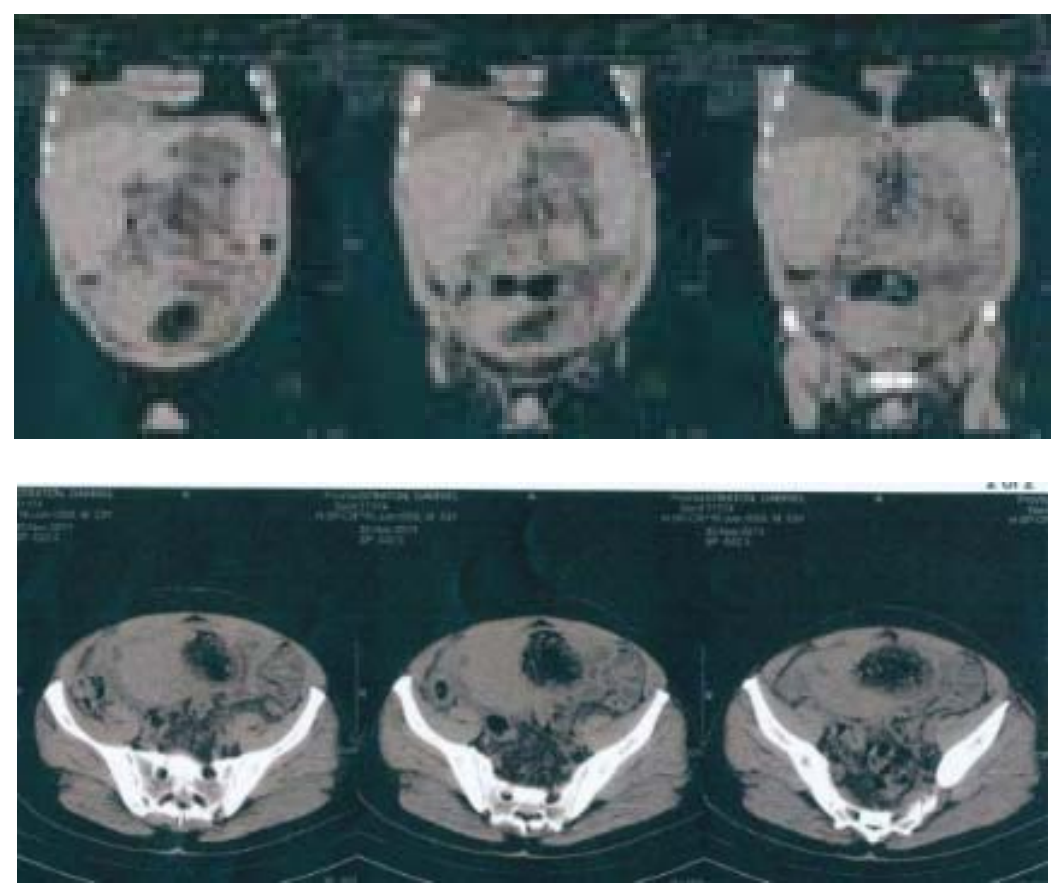

Figure 1.

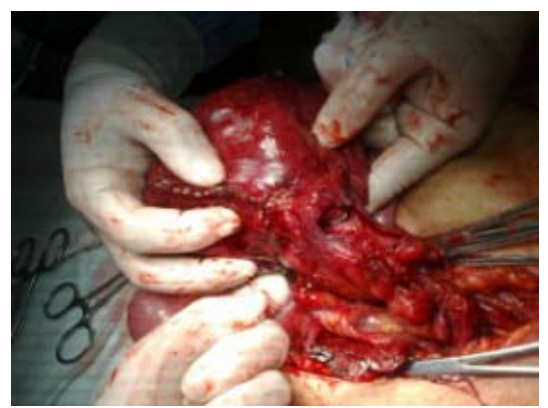

Figure 2. Terminal ileon tumor decollated from the pelvis.

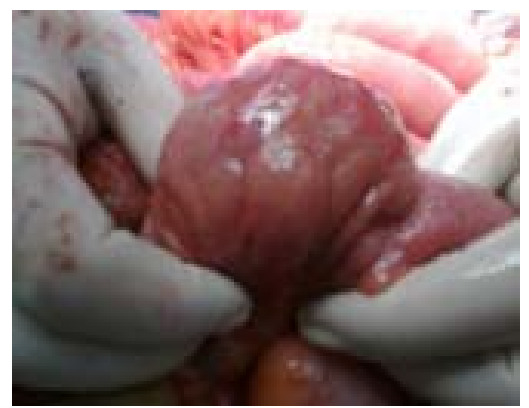

Figure 3. Mesoleium tumor (intraoperative). 


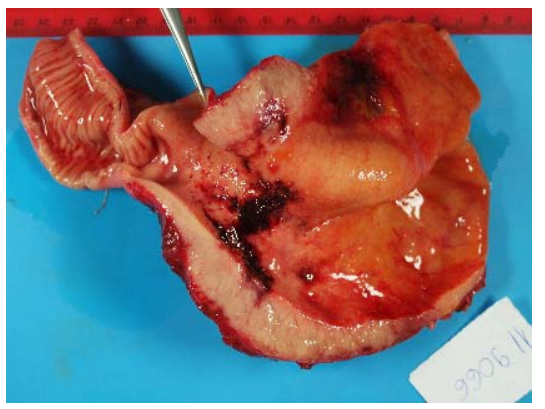

Figure 4. Enterectomy sample.

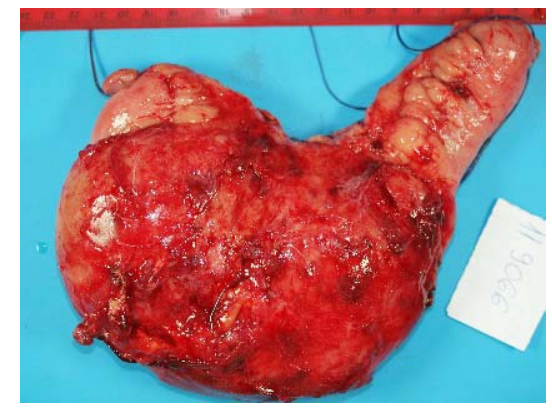

Figure 5. Enterectomy sample - sectioned.

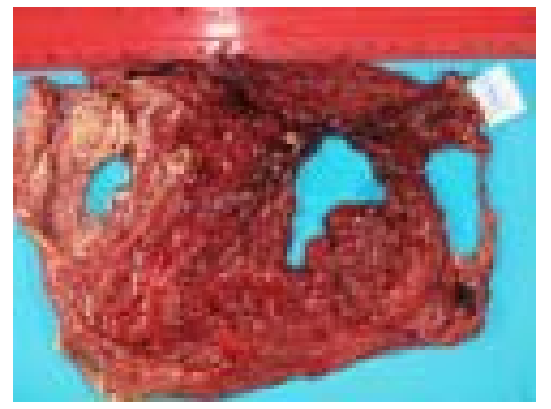

Figure 6. Omentectomy sample.

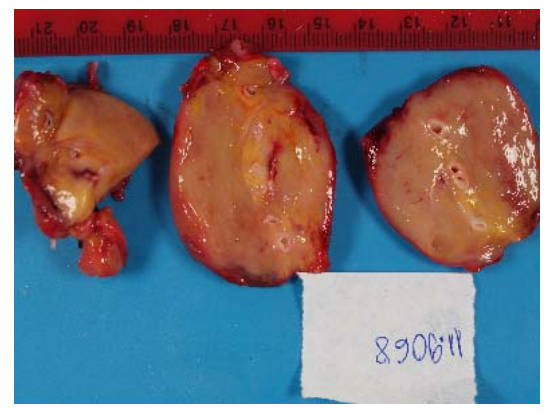

Figure 7. Appendectomy sample.

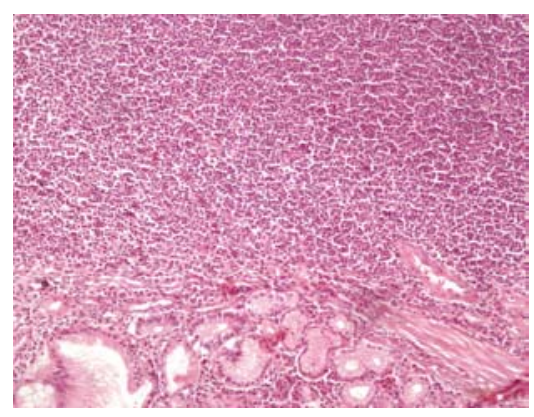

Figure 9. Small intestine glands; muscular mucosa; c. lymphoid proliferation.

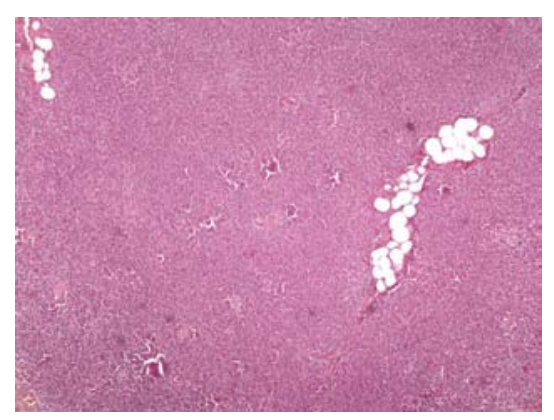

Figure 11. Monomorphic lymphoid infiltration with small cells with hypertrophic nuclei with minimal pleomorphism.

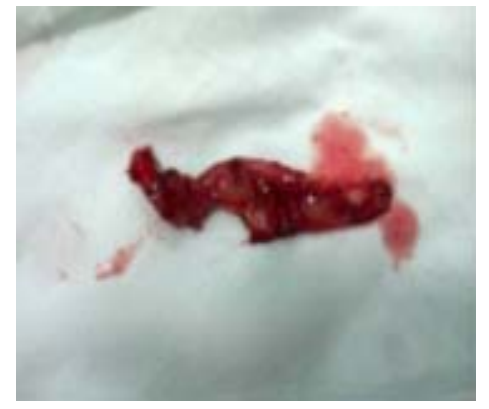

Figure 8. Mesenteric tumor - sectioned.

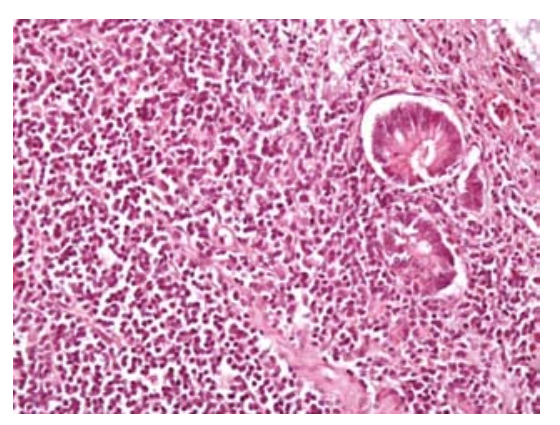

Figure 10. Intestinal gland lymphoid infiltrate and intraepithelial glandular structure dezorganization (lymphoepitelial lesion).

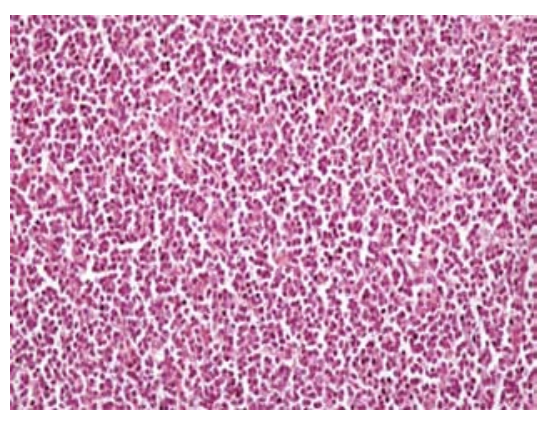

Figure 12. Lymphoid proliferation in mezoapendice, seizing small adipocyte lobules remaining. 


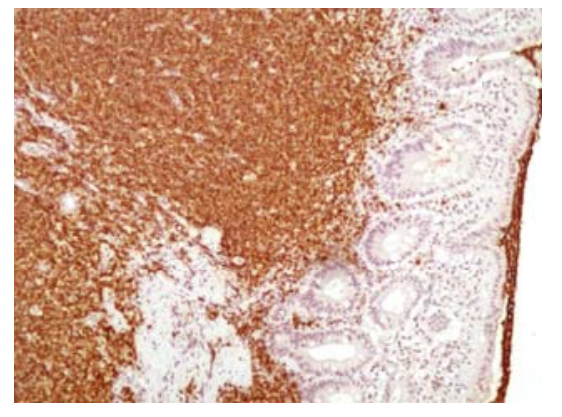

Figure 13. Lymphoid proliferation in intestinal meso, dissecting and replacing fat.

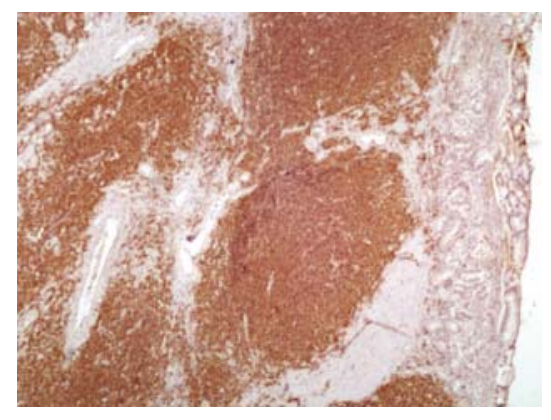

Figure 15. Positive CD20 in tumor cells (LyB marker).

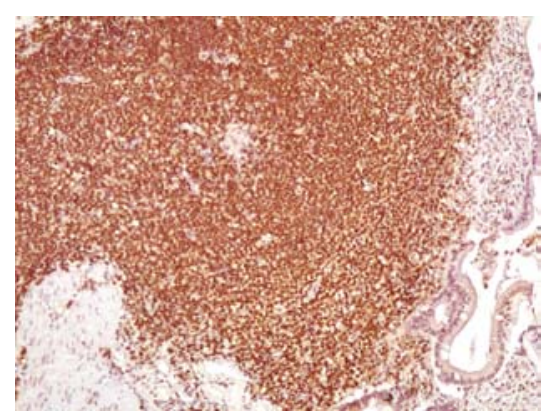

Figure 17. Positive $\mathrm{Bc} 12$ in tumor cells.

\section{FAVORABLE POSTOPERATIVE COURSE}

The patient was admitted in the Clinic of Hematology and he received chemo-therapy initiation - cure CHOP, well tolerated and Rithuximab 02/06/2012 for remission. The last admission in the hematologic unit was in January 2015 and found normal clinical aspects, with minimal hepato-splenomegaly and without any superficial and internal adenopathy. $\mathrm{He}$ will continue his bimonthly therapy with Rithuximab $700 \mathrm{mg}$.

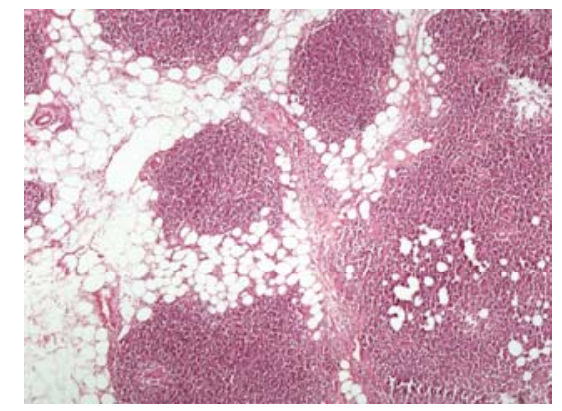

Figure 14. Positive CD20 in tumour cells (LyB marker); muscularis mucosae; intestinal glands.

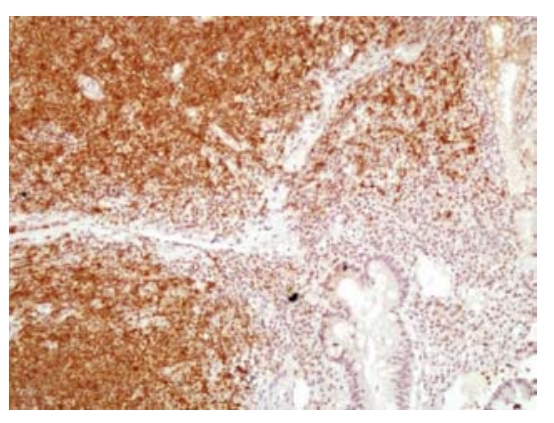

Figure 16. Positive CD22 in tumor cells.

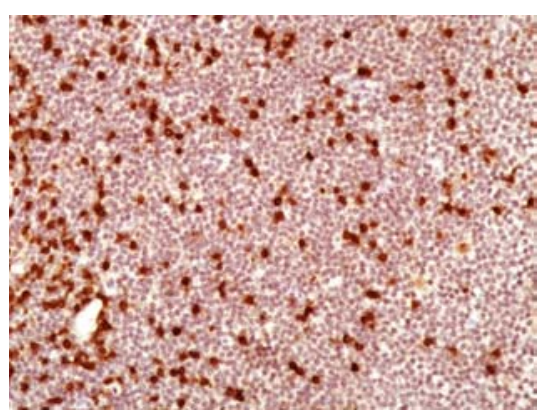

Figure 18. Negative tumor cells CD3, positive CD3 in reactive $\mathrm{T}$ lymphocytes, disseminated in tumor proliferation.

\section{DISCUSSION}

Intestinal localization of the lymphomas represents one of the most frequent situation met in the current practice. If we have the chance to find the illness in an initial stage, we can try to do a radical type of surgical intervention. But, in most cases, the surgeon is facing a situation when the lymphoma is in an advanced stage that does not allow a radical intervention, the operation having the goal to permit the patient to have a normal life, considering the digestive function, and the sampling 
of pathologic tissue for the histo-pathological exam. This is the one who will give us a positive diagnosis that will require the hematologic expertise for establishing the chemotherapy, including the use of monoclonal antibodies substances, for postoperative treatment that has the chance, sometimes, for a practically complete remission of the disease. This case presentation proves that, despite the advanced stage of the lymphoma and the patient's much altered general state at the moment of admission in our surgical clinic, the evolution after the proper treatment, including surgery and chemotherapy, was good and today, 4 years after the moment of diagnoses, the disease is practically in full remission.

\section{CONCLUSIONS}

Intestinal lymphomas can occur as primary tumors or in a systemic disease (6). They are usually associated with immunoproliferative diseases of the small intestine. It generally manifests by infiltrative and diffuse lesions, being most commonly localized on the proximal intestine [7]. The lymphomas can be Hodgkin or non-Hodgkin, the last type being classified in $\mathrm{B}$ cell or $\mathrm{T}$ cell lymphomas. It affects twice more often males, being met with a higher incidence in white people. The disease has two peaks of age, one under the age of 15 years and another in patients over 50 years [8].

The malignant tumors must be resected with oncological safety margin along the edge of the opposite side of the mesentery in order to remove the lymph locally, regional lymph nodes, to restore the continuity of the digestion. NHL nodular have a better prognosis compared to diffuse NHL. Type B lymphomas have better prognosis compared to type $\mathrm{T}$ lymphomas. Low malignacy lymphomas (B cells) have a longer evolution, but they rarely enter in complete remission.

Surgical treatment with excision of macroscopic lesions in conjunction with chemotherapy allows better control of the disease, and the patient has the chance even of healing ad integrum.

Tractul gastro-intestinal reprezintă cea mai frecventă localizare pentru limfoamele extralimfonodulare, intestinul subțire fiind afectat doar in $9 \%$ din cazuri. Limfoamele intestinale pot avea localizare unică sau multiplă. Articolul de față descrie un caz de localizare multiplă la nivelul intestinului subțire a unui limfom non-Hodgkin cu celule B, la un pacient în vîrstă de 53 de ani, care inițial a fost diagnosticat cu pneumonie cu pleurezie bilaterală cu E. coli mai accentuată pe partea dreaptă, dar la care persistența simptomelor sub formă de febră, stare generală alterată, in ciuda tratamentului adecvat, a impus continuarea investigațiilor, examenul CT decelând colecție fluidă în hipogastru cloazonată în jurul unei anse digestive. Pacientul a fost supus intervenției chirurgicale, intraoperator constatându-se prezența unei mari tumori mezenterice cu diametrul $\sim 5 \mathrm{~cm}$, a altei tumori mezenterice de ileon terminal, a încă unei tumori mezenterice cu diametrul $6 \mathrm{~cm}$, oment cu formațiuni nodulare, formațiune tumorală $\sim 3,3 / 2,5.1 \mathrm{~cm}$ la nivelul peretelui abdominal, apendice pseudotumoral. S-a practicat enterectomie segmentară cu entero-enterostomie, excizia tumorilor mezenterice, apendicectomie si omentectomie. Diagnosticul histopatologic a fost de limfom non-Hodgkin cu celule $B$ de zonă marginală tip MALT de intestin subțire cu extensie la nivelul apendicelui, mezoului, epiploonului şi peretelui abdominal. Postoperator, pacientul a beneficiat de tratament chimioterapic pentru obținerea remisiunii. 


\section{REFERENCES}

1. FRAMPAS E. Lymphomas: Basic points that radiologists should know. Diagn Interv Imaging. 2013; 94 (2):131-44.

2. TOMA P, GRANATA C, ROSSI A, et al. Multimodality imaging of Hodgkin disease and non-Hodgkin lymphomas in children. Radiographics. 2007; 27 (5): 1335-54 .

3. POSNER MITCHELL C, EVERETT E. VOKES, RALPH R. Weichselbaum and American Cancer Society. Cancer of the upper gastrointestinal tract. PMPH-USA, 2002.

4. OJHA A, ZACHERL J, SCHEUBA C, JAKESZ R, WENZL E. Primary small 1. bowel malignancies: single center results of three decades. J Clin Gastroenterol. 2000; 30:289-93.

5. ISAACSON PG. Gastrointestinal lymphoma. Hum Pathol. 1994; 25:1020-9.

6. KOCH P, DEL VALLE F, BERDEL WE, et al. Primary gastrointestinal non-Hodgkin's lymphoma: anatomic and histologic distribution, clinical features, and survival data of 371 patients registered in the German multicenter study git nhl 01/92. J Clin Oncol. 2001; 19:3861-73.

7. SALEM P, EL-HASHIMI L, ALLAM C. Primary small intestinal lymphoma in adults: a comparative study of IPSID versus non-IPSID in the Middle East. Cancer. 1987; 59:1670-

8. CHAO TC, CHAO HH, FAN YY, CHEN MF. J Gastroin Surg. 2005; 9:430-5.

9. WEISS NS, YANG CP. Incidence of histologic types of cancer of the small intestine. J Natl Cancer Inst. 1987; 78:653-6.

Received January 10, 2015 